\title{
The Phytotoxin Coronatine Contributes to Pathogen Fitness and Is Required for Suppression of Salicylic Acid Accumulation in Tomato Inoculated with Pseudomonas syringae pv. tomato DC3000
}

\author{
Srinivasa Rao Uppalapati, ${ }^{1,2}$ Yasuhiro Ishiga, ${ }^{1}$ Tamding Wangdi, ${ }^{1}$ Barbara N. Kunkel, ${ }^{3}$ Ajith Anand, ${ }^{2}$ \\ Kirankumar S. Mysore, ${ }^{2}$ and Carol L. Bender ${ }^{1}$ \\ ${ }^{1}$ Department of Entomology and Plant Pathology, Oklahoma State University, Stillwater 74078, U.S.A.; ${ }^{2}$ Plant Biology \\ Division, The Samuel Roberts Noble Foundation, 2510 Sam Noble Pkwy, Ardmore, OK 73401, U.S.A.; ${ }^{3}$ Department of \\ Biology, Washington University, St. Louis, MO 63130, U.S.A.
}

Submitted 8 January 2007. Accepted 9 April 2007.

\begin{abstract}
The roles of the phytotoxin coronatine (COR) and salicylic acid (SA)-mediated defenses in the interaction of Pseudomonas syringae pv. tomato DC3000 and tomato (Solanum lycopersicum) were investigated. Unlike findings reported for Arabidopsis thaliana, DC3000 mutants impaired for production of COR or one of its components, coronafacic acid (CFA) or coronamic acid (CMA), induced distinctly different disease lesion phenotypes in tomato. Tomato plants inoculated with the $\mathrm{CFA}^{-} \mathrm{CMA}^{-}$mutant DB29 showed elevated transcript levels of SIICS, which encodes isochorismate synthase, an enzyme involved in SA biosynthesis in $S$. lycopersicum. Furthermore, expression of genes encoding SA-mediated defense proteins were elevated in DB29-inoculated plants compared with plants inoculated with DC3000, suggesting that COR suppresses SIICS-mediated SA responses. Sequence analysis of SIICS revealed that it encodes a protein that is 55 and $59.6 \%$ identical to the $A$. thaliana ICS-encoded proteins AtICS1 and AtICS2, respectively. Tomato plants silenced for SIICS were hypersusceptible to DC3000 and accumulated lower levels of SA after infection with DC3000 compared with inoculated wild-type tomato plants. Unlike what has been shown for $A$. thaliana, the $\mathrm{COR}^{-}$mutant DB29 was impaired for persistence in SIICSsilenced tomato plants; thus, COR has additional roles in virulence that are $\mathrm{SA}$ independent and important in the latter stages of disease development. In summary, the infection assays, metabolic profiling, and gene expression results described in this study indicate that the intact COR molecule is required for both suppression of SA-mediated defense responses and full disease symptom development in tomato.
\end{abstract}

Plants have evolved various defense mechanisms to deal with the majority of potential microbial pathogens, and extensive progress has been made in understanding plant defense signaling pathways (Eulgem 2005; Katagiri 2004; Kunkel and Brooks

Corresponding author: C. L. Bender; Telephone: (+1) 405744 945; Fax: (+1) 405744 7373; E-mail: carol.bender@okstate.edu

Current address of S. R. Uppalapati: Plant Biology Division, The Samuel Roberts Noble Foundation, 2510 Sam Noble Pkwy, Ardmore, OK 73401.

* The $e$-Xtra logo stands for "electronic extra" and indicates that three supplemental figures are available online.
2002). The endogenous signaling molecules salicylic acid (SA), jasmonic acid (JA), and ethylene (ET) play major roles in the activation of defense responses to microbial pathogens (Dong 1998; Glazebrook 2005; Thomma et al. 2001). The roles of SA-, JA-, and ET-mediated signaling pathways vary in different plant-pathogen interactions (Kunkel and Brooks 2002; Lund et al. 1998; O'Donnell et al. 2003; Thomma et al. 2001). Mutual antagonism between the SA and JA pathways has been well documented (Glazebrook et al. 2003; Spoel et al. 2003; Thaler et al. 2002; Thomma et al. 2001). However, it is important to note that the interactions of JA and SA can also be synergistic (Imanishi et al. 2000; Mur et al. 2006); furthermore, spatial and temporal distribution can impact the outcome of JA-SA interactions (Truman et al. 2007).

SA-mediated defense signaling activates the expression of certain classes of pathogenesis-related (PR) proteins and results in defense against a number of pathogens (Delaney et al. 1994; Kunkel and Brooks 2002; Ryals et al. 1996; Shah 2003). In Arabidopsis thaliana, mutations that interfere with SA-mediated signaling or SA biosynthesis cause enhanced susceptibility to biotrophic pathogens, including Pseudomonas syringae (Cao et al. 1994; Delaney et al. 1994; Durner et al. 1997; Nawrath and Métraux 1999). Furthermore, it is well documented that expression of $n a h G$ (a gene encoding salicylate hydroxylase that degrades endogenous SA to catechol) in tobacco, tomato (Solanum lycopersicum), and A. thaliana compromises the resistance of these plants to several pathogens (Delaney et al. 1994; Glazebrook et al. 1996; Li et al. 2002; Oldroyd and Staskawicz 1998). Furthermore, Wildermuth and associates (2001) demonstrated that isochorismate synthase-mediated SA biosynthesis is required for pathogeninduced local and systemic resistance in A. thaliana.

Pathogens have evolved complex mechanisms to evade plant defense responses and cause disease in susceptible host plants (Abramovitch and Martin 2004; Espinosa et al. 2003; Jakobek et al. 1993; Uppalapati et al. 2004). P. syringae pv. tomato DC3000, which causes bacterial speck disease of tomato, $A$. thaliana, and Brassica spp., produces a plethora of virulence factors and effector proteins to suppress plant defense responses and promote disease physiology (Abramovitch and Martin 2004; Buell et al. 2003; Kunkel and Chen 2005; Mudgett 2005). To better understand the role of virulence factors in the suppression of plant defense responses, we have been studying the role of coronatine (COR), a non-host-specific phytotoxin, in 
$P$ syringae pathogenesis. The COR molecule consists of two components, coronafacic acid (CFA) and coronamic acid (CMA) (Bender et al. 1999). COR functions as a structural and functional analogue of JA and related signaling compounds, such as methyl jasmonic acid (MeJA), JA-isoleucine, and 12oxo-phytodienoic acid, the $\mathrm{C}_{18}$ precursor of JA/MeJA (Feys et al. 1994; Laurie-Berry et al. 2006; Weiler et al. 1994). COR is known to activate JA biosynthesis and JA-mediated signaling in both $A$. thaliana and tomato (Brooks et al. 2005; Thilmony et al. 2006; Uppalapati et al. 2005; Zhao et al. 2003).

COR plays several important roles during $P$. syringae pathogenesis. Recent studies demonstrate that COR facilitates the entry of $P$. syringae into $A$. thaliana tissue by suppressing the closure of stomata, a basal defense response induced upon microbial attack (Melotto et al. 2006). COR also is required for growth and persistence in plant tissue (Bender et al. 1987; Brooks et al. 2004; Elizabeth and Bender 2007; Mittal and Davis 1995). It has been proposed that COR-induced JA signaling is required to promote in planta growth and for suppression of SA-dependent defenses in A. thaliana and tomato (Block et al. 2005; Brooks et al. 2005; Kloek et al. 2001; LaurieBerry et al. 2006; Zhao et al. 2003). Consistent with this hypothesis, the growth of COR mutants is fully restored in $A$. thaliana lines deficient for SA accumulation (Brooks et al. 2005), suggesting that COR is required for overcoming SAmediated defenses. Additionally, COR is required for the development of typical bacterial speck lesions in A. thaliana, even in situations where growth of the COR-defective strains is similar to the levels achieved by wild-type DC3000 (Brooks et al. 2005). These studies, which involved the comparison of mutants defective in CFA, CMA, or COR synthesis, also revealed that neither CFA nor CMA alone contributes significantly to virulence in A. thaliana (Brooks et al. 2004).

The roles of COR, CFA, and CMA during pathogenesis of DC3000 on tomato are not well understood. Unlike what has been reported for $A$. thaliana, a previous study using purified compounds (Uppalapati et al. 2005) suggested that CFA, CMA, and COR may play individual roles in interactions with tomato. Additionally, the defense-signaling pathways in tomato and A. thaliana are modulated differently (Brading et al. 2000; Leon et al. 2001; Lim and Kunkel 2005). Thus, COR may function differently in tomato and A. thaliana, and the nature of this difference warrants further investigation. Furthermore, it is unwise to base our understanding of COR function on the analysis of a single host species. To investigate the importance of COR, CFA, and CMA in pathogenic interactions between DC3000 and tomato, we utilized a set of well-defined COR biosynthetic mutants (Brooks et al. 2004) that are defective in production of CFA (DB4G3; $c f a 6:: T n 5)$, CMA (AK7E2; $c m a A:: \operatorname{Tn} 5)$, and COR (DB29; cfa6-cmaA double mutant). Tomato lines that were compromised for SA biosynthesis were developed by silencing the gene encoding isochorismate synthase (ICS, a gene implicated in SA biosynthesis in $A$. thaliana) using virus-induced gene silencing (VIGS). Results obtained from virulence assays, metabolic profiling, and gene expression studies indicate that the intact COR molecule is required for suppression of SA-mediated defense responses, the formation of typical disease symptoms, and persistence of DC3000 in tomato.

\section{RESULTS}

\section{Role of COR, CFA, and CMA in pathogenesis.}

The bacterial population dynamics and disease phenotype of tomato plants (cv. Glamour) spray inoculated with COR biosynthetic mutants were investigated to determine the role of COR, CFA, and CMA in pathogenesis. Spray-inoculated plants were incubated in growth chambers with high relative humidity (RH) (90 to $100 \%$ ) for the first $24 \mathrm{~h}$ and approximately $70 \%$ $\mathrm{RH}$ for the remainder of the experimental period. The wildtype DC3000 and COR-defective mutants showed similar growth characteristics in tomato cv. Glamour from 0 to 3 days postinoculation (dpi) (Fig. 1A). However, at $6 \mathrm{dpi}$, there was a significant difference in the population of DC3000 and the $\mathrm{COR}^{-}$mutants (Fig. 1A). The $\mathrm{COR}^{-}$mutants exhibited reduced persistence compared with DC3000, and the double mutant DB29 ( cfa6-cmaA, $\mathrm{CFA}^{-} \mathrm{CMA}^{-}$) was more impaired in its ability to persist compared with the single mutants (Fig. 1A). The inability of the three mutants to maintain a high population density at 6 dpi indicates that both components of COR are important for pathogen persistence in tomato tissue.

The wild-type DC3000 strain elicited typical bacterial speck symptoms on tomato, which consisted of dark brown, necrotic lesions surrounded by yellow, chlorotic halos (Fig. 1B). The three $\mathrm{COR}^{-}$mutants exhibited distinctly different disease lesion phenotypes on tomato (Fig $1 \mathrm{C}-\mathrm{E}$ ). For example, AK7E2 $\left(\mathrm{CFA}^{+} \mathrm{CMA}^{-}\right)$induced a small number of necrotic lesions, and these were surrounded by chlorotic halos (Fig. 1C). In contrast, DB4G3 $\left(\mathrm{CFA}^{-} \mathrm{CMA}^{+}\right)$induced numerous small necrotic lesions that lacked chlorotic halos (Fig. 1D). Tomato plants inoculated with DB29 $\left(\mathrm{CFA}^{-} \mathrm{CMA}^{-}\right)$did not show any visible symptoms (Fig. 1E). Thus, both components of COR (e.g., CFA and CMA) contribute differentially to symptom development in tomato.

\section{COR stimulates JA signaling in tomato.}

The virulence assays described above (Fig. 1) demonstrated that the intact COR molecule is required for full symptom development in tomato. Previous results obtained using a $\mathrm{COR}^{-}$ mutant (Ma et al. 1991) and Northern blot analysis suggested that COR stimulates the JA pathway in tomato (Zhao et al. 2003), similar to what has been observed in A. thaliana (Block et al. 2005; Brooks et al. 2005; Schmelz et al. 2003; Thilmony et al. 2006). To further investigate the role of COR in tomato, plants were inoculated with DC3000 and the biochemically defined $\mathrm{COR}^{-}$mutant DB29, and real-time quantitative polymerase chain reaction (qPCR) was used to follow the expression of LOXD (Heitz et al. 1997) and PI-II (Pena-Cortes et al. 1995), which are involved in JA biosynthesis and production of JA-inducible serine proteinase inhibitors, respectively. In DC3000-inoculated plants, the expression of LOXD (Fig. 2A) and PI-II (Fig. 2B) was induced to relatively high levels when compared with mock-inoculated plants. However, in plants inoculated with DB29, induction of LOXD (Fig. 2A) and PI-II (Fig. 2B) was much lower than in plants inoculated with DC3000, thus confirming that COR stimulates JA signaling in tomato.

\section{COR downregulates SA-dependent defenses in tomato.}

Recently, Brooks and associates (2005) used a set of defined $\mathrm{COR}^{-}$mutants (DB4G3, AK7E2, and DB29) to show that COR contributes to $P$. syringae virulence by suppressing SAmediated defense responses in A. thaliana, a finding later confirmed by Thilmony and associates (2006). In tomato, the role of COR in suppressing SA-mediated defenses has been suggested (Zhao et al. 2003), but not confirmed using biochemically defined $\mathrm{COR}^{-}$mutants. In the current study, tomato was inoculated with DC3000 and DB29, and the expression of the SA-dependent PR genes $P R-1 b$ and $P R-2 b$ (Brading et al. 2000; Vidya et al. 1999; Zhao et al. 2003) was monitored by real-time qPCR. In tomato plants inoculated with DC3000, expression of $P R-1 b$ and $P R-2 b$ was significantly lower than in DB29-inoculated leaves (Fig. 2C and D), which supports a role for COR in suppressing SA-dependent defenses in tomato. 


\section{COR suppresses SA biosynthesis and expression} of pathogen-inducible SlICS.

The real-time qPCR experiments described above (Fig. 2C and D) did not indicate whether COR suppresses $P R$ gene expression by interfering with SA accumulation or with SAmediated signaling. This was explored by quantifying SA levels in plants inoculated with DC3000 and the $\mathrm{COR}^{-}$mutant DB29. Inoculation of tomato plants with DC3000 resulted in an increase in SA levels (Fig. 3A), similar to what has been reported for $P$. syringae-infected $A$. thaliana (Nawrath and Metraux 1999; Schmelz et al. 2003). Tomato plants inoculated with DB29 contained significantly higher levels of SA than those inoculated with the wild-type DC3000 (Fig. 3A), thus indicating that COR inhibits SA accumulation in tomato.

In A. thaliana, the biosynthesis of SA during pathogenesis requires $I C S 1$, which encodes isochorismate synthase (Wildermuth et al. 2001). As described above, SA is produced during the infection of tomato by DC3000, and the production of
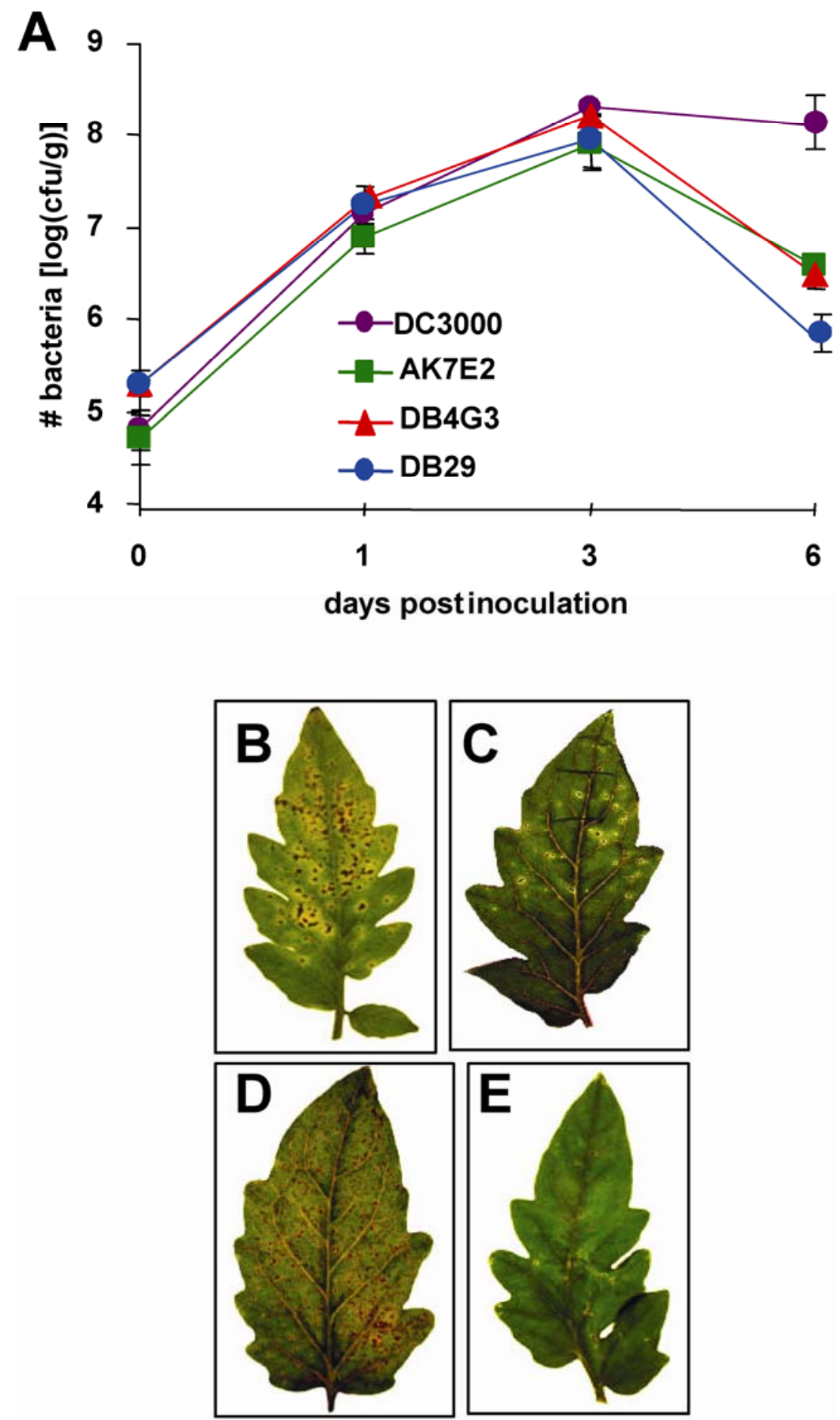

Fig. 1. Population dynamics and disease phenotypes of Pseudomonas syringae pv. tomato DC3000 and coronatine (COR) biosynthetic mutants in wild-type (cv. Glamour) tomato plants. A, Internal bacterial populations in plants spray inoculated with DC3000, AK7E2 (CFA ${ }^{+} \mathrm{CMA}^{-}$; cmaA::Tn5), DB4G3 (CFA $\mathrm{CMA}^{+}$; cfa6::Tn5), and DB29 (COR ${ }^{-} \mathrm{CFA}^{-} \mathrm{CMA}^{-} ;$cfa6-cmaA double mutant). The errors bars indicate the standard deviation, and each assay was done at least three times with similar results. B through E, Symptoms on tomato plants spray inoculated with B, DC3000; C, AK7E2; D, DB4G3; and E, DB29. Photos were taken at 6 days postinoculation. 
COR by DC3000 decreased the level of SA relative to that present in DB29-inoculated plants (Fig. 3A). However, it was not clear whether the biosynthesis of SA in tomato was modulated via ICS during pathogenesis. This was investigated by monitoring expression of the tomato (S. lycopersicum) homologue of ICS (SIICS) using real-time qPCR. Consistent with observations that DB29-inoculated plants accumulated increased amounts of SA (Fig. 3A) and SA-dependent $P R$ transcripts (Fig. 2C and D), the expression of SlICS was approximately twofold higher in leaves inoculated with DB29 compared with DC3000 (Fig. 3B). The correlation between SA accumulation and SIICS expression (Fig. 3A and B) suggests that SIICS mediates pathogen-induced SA accumulation in tomato.

In A. thaliana, two ICS genes were reported; however, only AtICS1 is implicated in pathogen-induced SA biosynthesis (Wildermuth et al. 2001). To investigate whether the SIICS transcript monitored during pathogenesis of tomato encodes a functional, full-length ICS and whether multiple transcripts of
ICS exist in tomato, rapid amplification of cDNA ends (RACE)-PCR was utilized. RACE-PCR of the cDNA isolated from pathogen- or mock-inoculated tomato tissues indicated the presence of one full-length transcript (data not shown). Sequence analysis of the cDNA showed that SIICS encodes a protein of 580 amino acid residues (Supplementary Fig. S1; GenBank accession number DQ984132). SIICS is highly related to ICS proteins from Capsicum annuum and Catharanthus roseus, which showed 91.7 and $58.8 \%$ amino acid identity to SIICS, respectively. Furthermore, SIICS showed 55 and $59.6 \%$ identity to AtICS1 and AtICS2 from A. thaliana, respectively.

\section{$\mathrm{SA}$ is required}

for defense responses in tomato inoculated with DC3000.

Previous studies using A. thaliana sid 2 mutants, which carry a mutation in ICS1, provided direct genetic evidence for the role of ICSI-mediated SA accumulation in plant defense (Heck et al. 2003; Nawrath and Metraux 1999; Wildermuth et

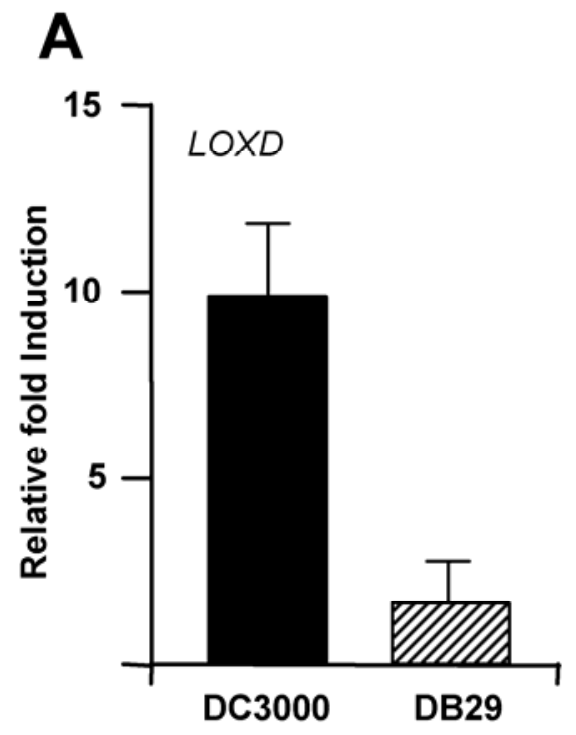

B
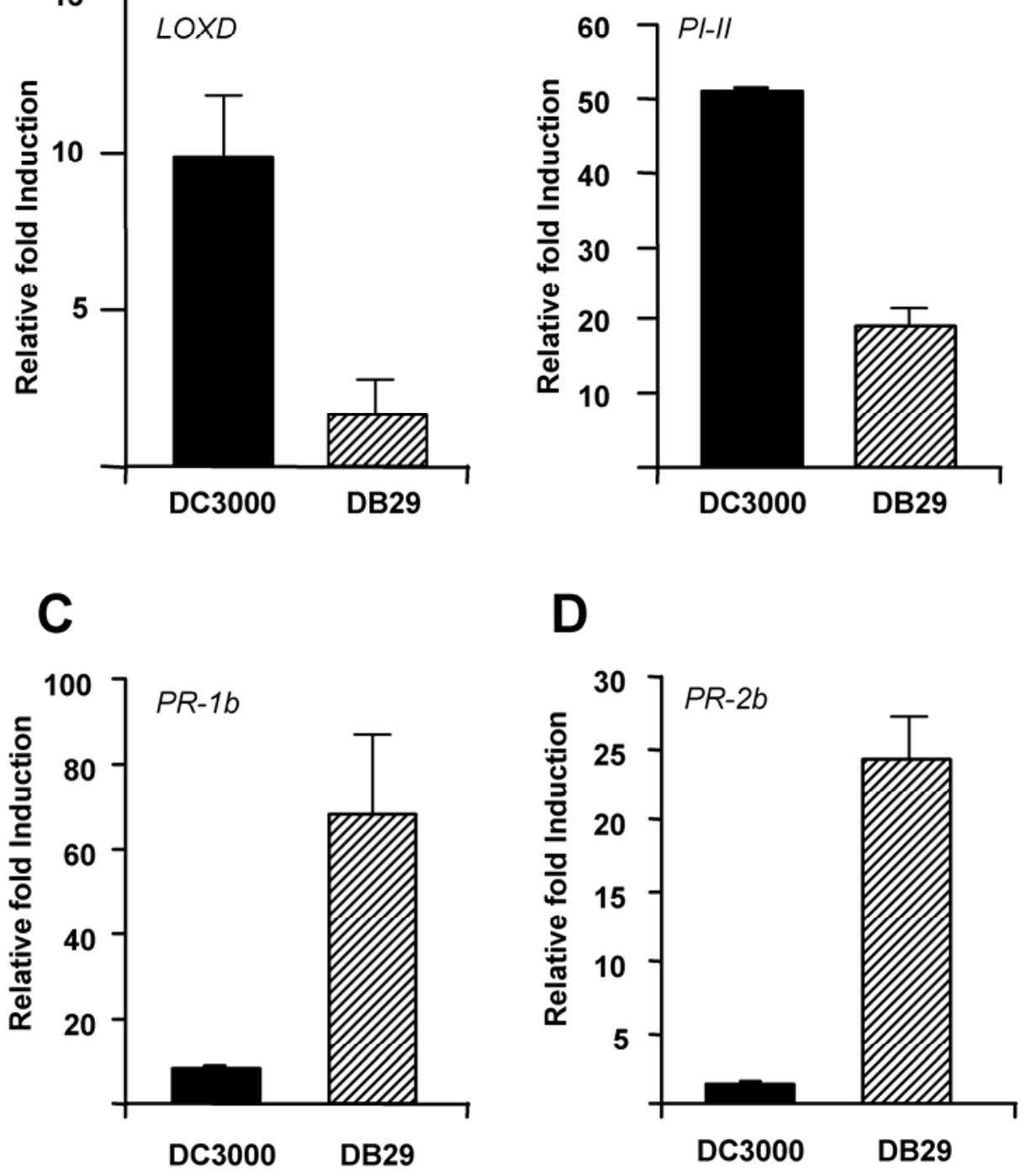

Fig. 2. Coronatine (COR) induces the jasmonic acid (JA) pathway and suppresses salicylic acid (SA)-mediated pathogenesis-related (PR) gene expression in tomato. Transcriptional changes in gene expression were analyzed at $24 \mathrm{~h}$ post inoculation using real-time quantitative polymerase chain reaction. Panels show expression of $\mathbf{A}, L O X D$, which encodes lipoxygenase, an enzyme involved in JA biosynthesis; B, PI-II, which encodes a JA- or wound-inducible serine proteinase inhibitor; and the SA markers $\mathbf{C}, P R-1 b$ and $\mathbf{D}, P R-2 b$. The results show changes in gene expression in tomato cv. Glamour leaves inoculated with DC3000 or DB29 $\left(\mathrm{COR}^{-}\right)$. The values represent the average of three independent biological replicates. The gene encoding $\alpha$-tubulin 4 ( $\left.\alpha-T U B\right)$ was used as an internal control. 
al. 2001). To investigate the functional role of SlICS in DC3000-tomato interactions, VIGS was used for transient knockdown of SIICS in tomato cv. Glamour. A partial tomato expressed sequence tag (440 bp; GenBank accession number DQ149918) was generated using primers based on known plant ICS genes (see Methods) and cloned into Tobacco rattle virus (TRV)-based VIGS vectors (Liu et al. 2002). The resulting construct was used to infect tomato, and several plants were infected with an empty vector control (TRV:00) for comparison. Silencing of SIICS in tomato occasionally resulted in a variegated leaf phenotype, with leaves exhibiting pale green patches (data not shown). To check the efficiency of silencing, the relative inhibition of SIICS transcripts was quantified 2 to 3 weeks postsilencing by semiquantitative reverse-transcriptase

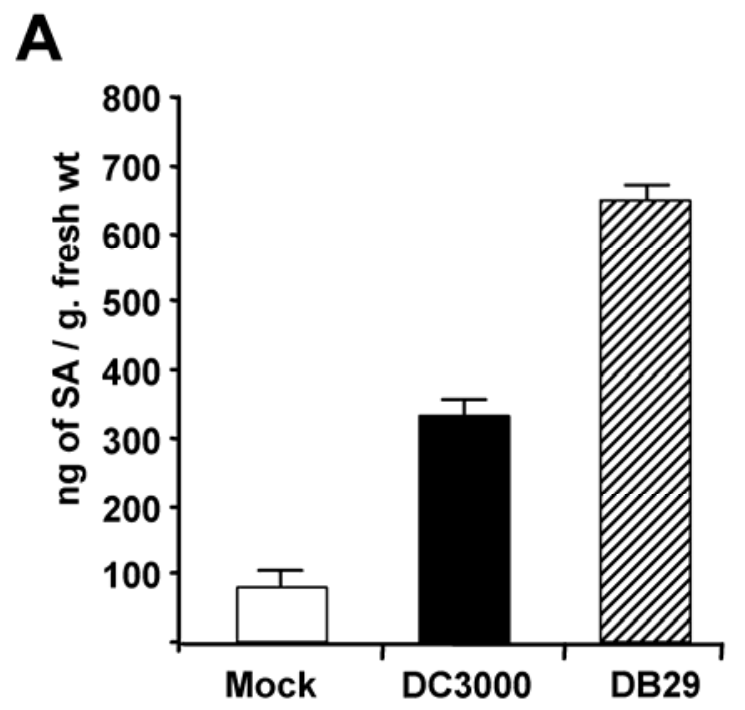

B

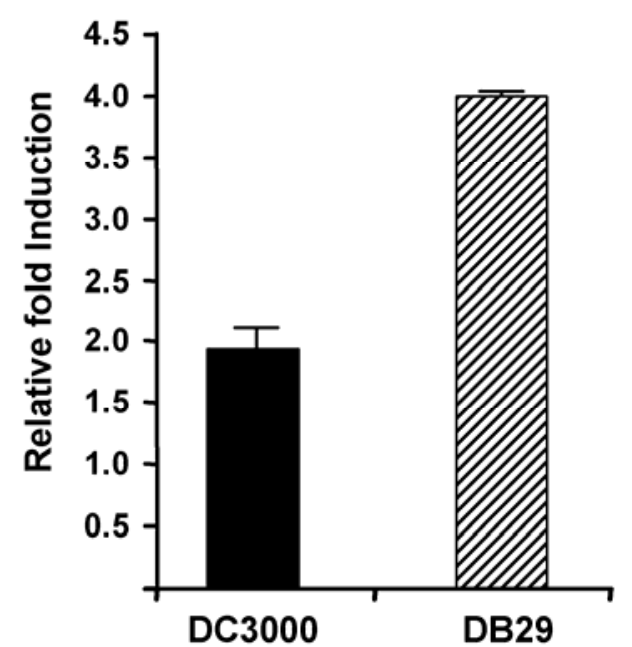

Fig. 3. Coronatine (COR) suppresses pathogen-induced salicylic acid (SA) accumulation and SIICS in tomato. A, Changes in SA levels in tomato leaves inoculated with water (mock-inoculated control), DC3000, or DB29 $\left(\mathrm{COR}^{-}\right)$at $24 \mathrm{~h}$ post inoculation (hpi). Error bars represent the standard deviation. Samples from six independent plants were pooled, and SA was quantified from three pooled samples collected from independent experiments. B, Fold changes in SIICS expression at 24 hpi as detected by realtime quantitative polymerase chain reaction in tomato leaves inoculated DC3000 or DB29. SlICS induction is shown relative to levels of SIICS in mock-inoculated tissues. The gene encoding $\alpha$-tubulin 4 was used as an internal control. The values represent average of three replicates. Similar trends were observed in three independent biological experiments.
(RT)-PCR and the intensities of the PCR products were quantified (Fig. 4). Using this approach, SIICS mRNA levels were substantially lower (approximately 70\%) in leaf tissue collected from the second and third leaflets of the TRV::SlICS plants compared with TRV:00 plants (Fig. 4). It is important to mention that the apical leaflets showed more silencing due to systemic VIGS; therefore, the second and third leaves located beneath the apical leaf were used for all pathogen assays.

TRV:00 and TRV::SIICS tomato lines were either mock-inoculated or infected with DC3000 and analyzed for SA levels. SA accumulation was similar in mock-inoculated TRV:00 and TRV:SIICS plants (Fig. 5A). However, when inoculated with DC3000, SA levels were significantly lower in TRV::SIICS lines compared with TRV::00 plants (Fig. 5A). These results indicate that SIICS modulates SA accumulation in tomato lines inoculated with $P$. syringae, thus confirming the validity of using TRV::SlICS lines in the experiments described below.

The contribution of SIICS-mediated SA to symptom development was investigated by spray inoculating TRV:00 (mock control) and SlICS-silenced plants with DC3000. Both TRV::00infected and SIICS-silenced tomato leaves developed bacterial speck lesions when inoculated with DC3000 (Fig. 5E and H). Interestingly, the progression of the disease was faster and enhanced in SIICS-silenced plants, which developed large coalescing lesions by 6 dpi (Fig. 5H) compared with TRV::00infected plants (Fig. 5E). These results suggest that SA may function to limit the severity of bacterial speck disease in tomato.

To explore whether the accelerated symptom development in SIICS-silenced plants was correlated with increased bacterial growth, the population of DC3000 in TRV::00- and TRV::SlICS-infected tomato lines was monitored over time. At $1 \mathrm{dpi}$, the population of DC3000 was approximately 50-fold higher in TRV::SlICS plants compared with TRV::00 lines (Fig. 5B). Although the population of DC3000 was consistently higher on TRV::SIICS tomato lines than the control (TRV::00) at 2 and $3 \mathrm{dpi}$, there was no significant difference at 4 dpi (Fig. 5B). Interestingly, very low numbers of DC3000 cells were recovered from TRV::SIICS tissues showing severe necrosis (data not shown). Collectively, the accelerated disease progression and the ability of DC3000 to multiply to high levels on TRV::SIICS plants in the initial stages of infection indicate that SA functions to limit DC3000 colonization in tomato.

\section{ICS-mediated SA is involved}

in pathogen-induced $P R-1 b$ expression.

We then investigated whether SIICS-silenced plants were compromised in SA-dependent $P R$ gene expression. The level of $P R-1 b$ expression in TRV::00-infected plants was higher in plants challenged with DB29 compared with DC3000-inoculated plants (Fig. 6, compare lanes 2 and 3). $P R-1 b$ expression generally was lower in SIICS-silenced plants inoculated with

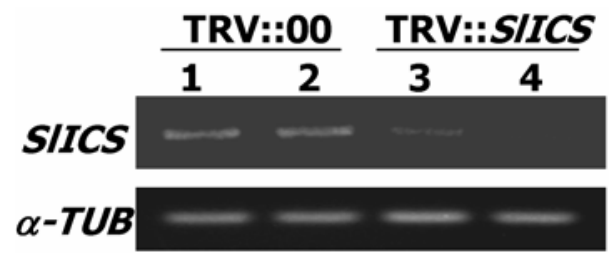

Fig. 4. Efficiency of SIICS silencing in tomato as indicated by semiquantitative reverse-transcriptase polymerase chain reaction (RTPCR). Total RNA was extracted from the second (lanes 1 and 3) and third (lanes 2 and 4) leaves below the apical leaf. Plants were infected with TRV::00 (vector control) or TRV::SlICS and analyzed by semiquantitative RT-PCR 3 weeks post agroinoculation. The PCR product for primers specific to $\alpha$-tubulin $4(\alpha-T U B)$ was used as a loading control. 
DC3000 and DB29 (Fig. 6, lanes 4 to 7). It is important to note that the RNA shown in Figure 6 was isolated from independent leaf tissues, and silencing varied among different leaves; thus, some leaves showed low levels of $P R-1 b$ expression (Fig. 6, lane 5). Overall, these results indicate that SIICS-silenced plants were compromised in SA-dependent $P R$ gene expression.

\section{COR is required}

for pathogen fitness and disease development.

The $\mathrm{COR}^{-}$mutant DB29 was impaired in its ability to induce disease and maintain high population densities in tomato cv. Glamour (Fig. 1A and E). This prompted us to ask whether a reduction in SA levels could restore virulence and persistence to DB29, a question that was investigated using SIICSsilenced lines of tomato. Neither TRV::00 nor TRV::SIICS plants spray inoculated with DB29 developed typical disease symptoms (Fig. 7B and C). At 6 dpi, DB29 was unable to persist at high levels in TRV::00 (vector control) or TRV::SIICS plants (Fig. 7A). Thus, the elimination of pathogen-inducible SA did not restore persistence to DB29 in tomato cv. Glamour, which is different from results obtained in A. thaliana (Brooks et al. 2005).
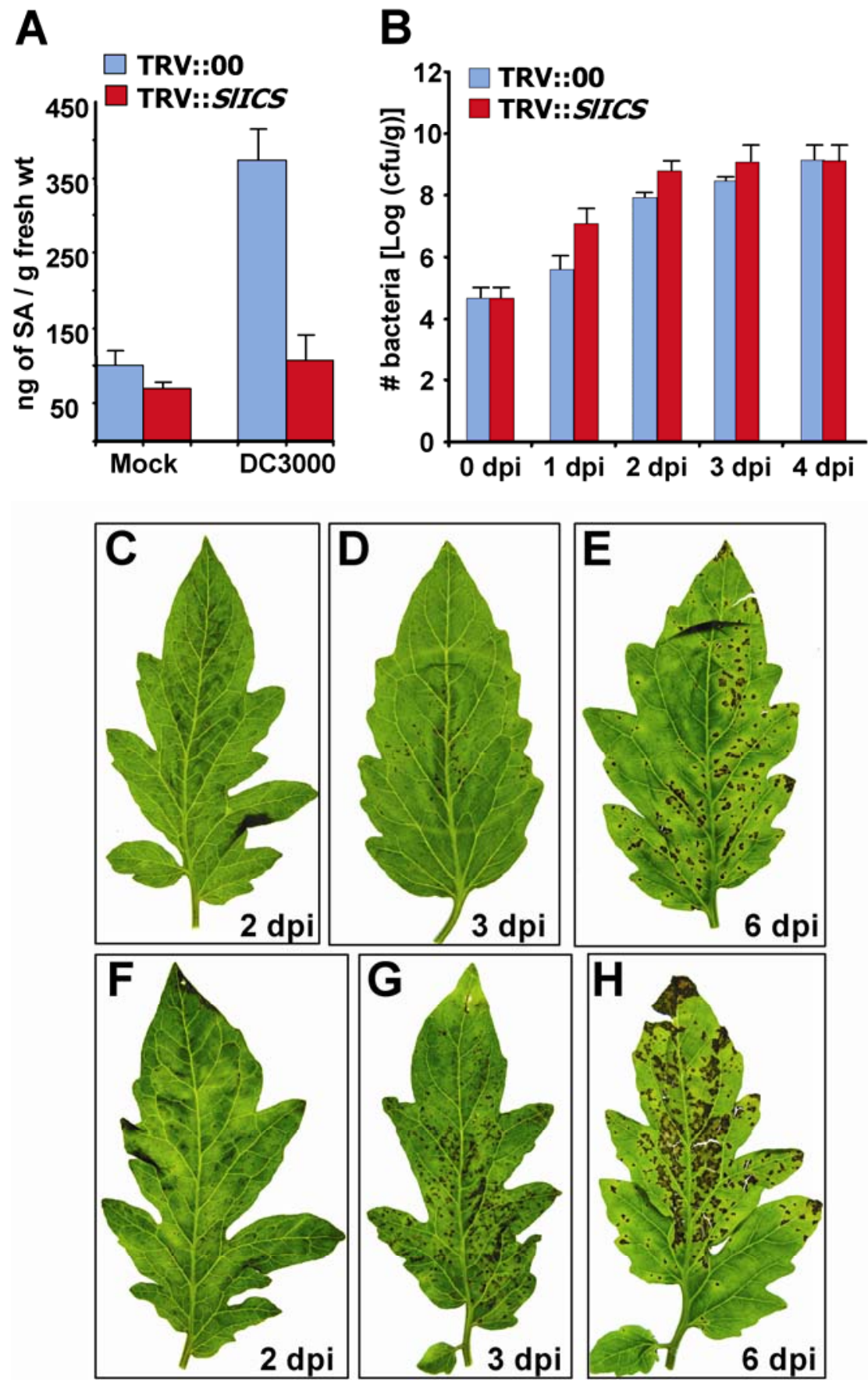

Fig. 5. Salicylic acid (SA) levels, bacterial growth, and symptom production in DC3000-inoculated TRV::00 and SlICS-silenced tomatoes (cv. Glamour). A, SA levels in TRV::00 and TRV::SlICS plants. SA was quantified using gas chromatography-mass spectrometry as described in Methods. B, Growth of DC3000 in TRV::00 and TRV::SlICS plants. The total bacterial population was estimated by collecting leaf discs at various time points from areas where maximum silencing was observed based on a slightly variegated phenotype. All treatments were examined in at least three separate experiments. Error bars in panels $\mathbf{A}$ and $\mathbf{B}$ represent the standard deviation of four independent samples. $\mathbf{C}$ through $\mathbf{H}$, Symptoms produced by DC3000 on $\mathbf{C}$ through $\mathbf{E}$, TRV::00 and $\mathbf{F}$ through $\mathbf{H}$, TRV::SlICS plants at 2, 3, and 6 days post inoculation (dpi). 


\section{DISCUSSION}

In this study, well-defined COR biosynthetic mutants were used to study the role of COR in disease development and suppression of SA-mediated defense responses. The results indicate important differences for COR and its components (CFA and CMA) in the interaction of DC3000 with tomato compared with $A$. thaliana. In tomato, mutant strains AK7E2 and DB4G3 induced distinct disease lesion phenotypes, unlike $A$. thaliana (Brooks et al. 2004). The $\mathrm{CFA}^{+} \mathrm{CMA}^{-}$mutant AK7E2 induced a small number of chlorotic bacterial specks on tomato (Fig. 1C). Because the exogenous application of CFA to tomato does not induce visible chlorosis (Uppalapati et al. 2005), the chlorotic lesions observed in AK7E2-inoculated plants may be due to the production of coronafacoyl amide conjugates such as coronafacoylisoleucine and coronafacoylvaline; these conjugates are less toxic than COR but still induce chlorosis (Mitchell 1984; Mitchell and Ford 1998; Uppalapati et al. 2005). The CFA ${ }^{-} \mathrm{CMA}^{+}$mutant DB4G3 produced necrotic lesions lacking chlorotic halos, although the lesion size was reduced compared with DC3000 (Fig. 1D). Because exogenous CMA is known to induce some JA-responsive genes in tomato (Uppalapati et al. 2005), it remains possible that DB4G3 produced CMA that becomes conjugated to JA (Staswick and Tiryaki 2004; Uppalapati et al. 2005), and CMA-JA conjugates may alter the host physiology and contribute to the disease phenotype. In summary, results obtained using biochemically defined $\mathrm{COR}^{-}$mutants indicate that neither CFA nor CMA alone is sufficient to cause full disease symptoms in tomato, and that each molecule may contribute individually to symptom development.

Melotto and associates (2006) recently demonstrated that bacterial multiplication was impaired in A. thaliana plants dip inoculated with a $\mathrm{COR}^{-}$mutant. This multiplication defect was observed in the early stages of infection (3 dpi) and was not observed in plants inoculated with the wild-type COR-producing DC3000. Melotto and associates (2006) provide compelling evidence that COR suppresses stomatal-mediated defense mechanisms, thus facilitating the entry of pathogenic bacteria into the plant. In our study, a difference in the initial multiplication of $\mathrm{COR}^{+}$and $\mathrm{COR}^{-}$bacteria was not observed; instead, $\mathrm{COR}^{-}$bacteria were impaired in their ability to persist in planta in the later stages of infection (e.g., $6 \mathrm{dpi}$ ). A persistence defect was observed previously in A. thaliana plants vacuum infiltrated with the $\mathrm{COR}^{-}$mutants used in the present study (Brooks et al. 2004). Although we did not see the entry defect described by Melotto and associates (2006), it is important to note that

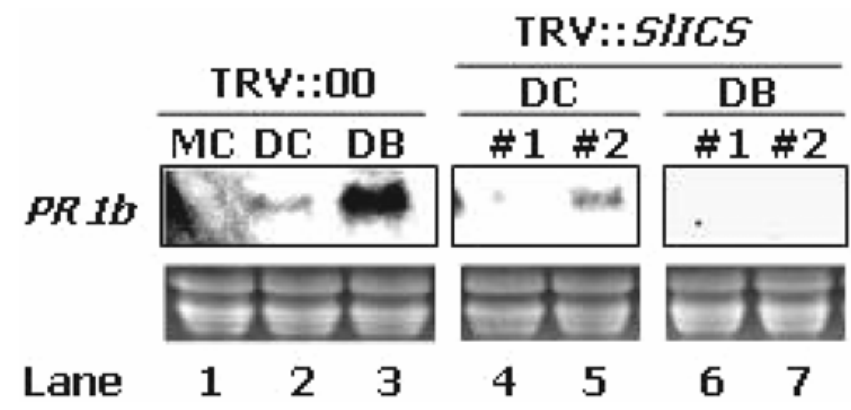

Fig. 6. Northern blot analysis of $P R-1 b$ expression in TRV::00 or TRV::SIICS tomato lines inoculated with Pseudomonas syringae pv. tomato. Total RNA was isolated from TRV::00 plants (lanes 1 to 3 ) or TRV::SlICS lines (lanes 4 to 7) $24 \mathrm{~h}$ after inoculation with water (MC, mock control), DC3000 (DC), or DB29 (DB). To check the uniformity and efficiency of SIICS silencing, leaves were harvested from two independent pathogen-inoculated plants (designated lines \#1 and \#2) 2 weeks after infection with TRV::SIICS Northern blots were probed with $P R-1 b$-specific cDNAs. the methods used for inoculation and the environmental conditions in the early stages of infection were different in our study and similar to those used by Brooks and associates (2005). Thus, our infection methods may have impacted the bacterial population and possibly masked the function of COR in initial entry.

Our results using well-defined $\mathrm{COR}^{-}$mutants further demonstrate that COR activates the JA pathway in tomato (Fig. 2A and $\mathrm{B})$, which also has been reported for tomato treated with exogenous COR (Uppalapati et al. 2005). A popular theory is that COR functions as analogue of JA and antagonizes SA-mediated defense responses (Kloek et al. 2001; Zhao et al. 2003). In the present study, SA accumulation and $P R$ gene expression were higher in tomato leaves inoculated with the COR-defective mutant DB29 compared with DC3000-infected tissue. Thus, our results support the hypothesis that COR functions to suppress SA and SA-mediated defenses in tomato (Figs. 2 and 3).

To further evaluate the role of SA in DC3000-tomato interactions, we initially used tomato lines expressing $N a h G$ (Brading et al. 2000), which encodes salicylate hydroxylase. NahG degrades salicylate to catechol and has been widely used to evaluate the role of SA in plant-microbe interactions. Unlike the parental line Moneymaker, which developed typical bacterial speck lesions in response to DC3000 (Supplementary

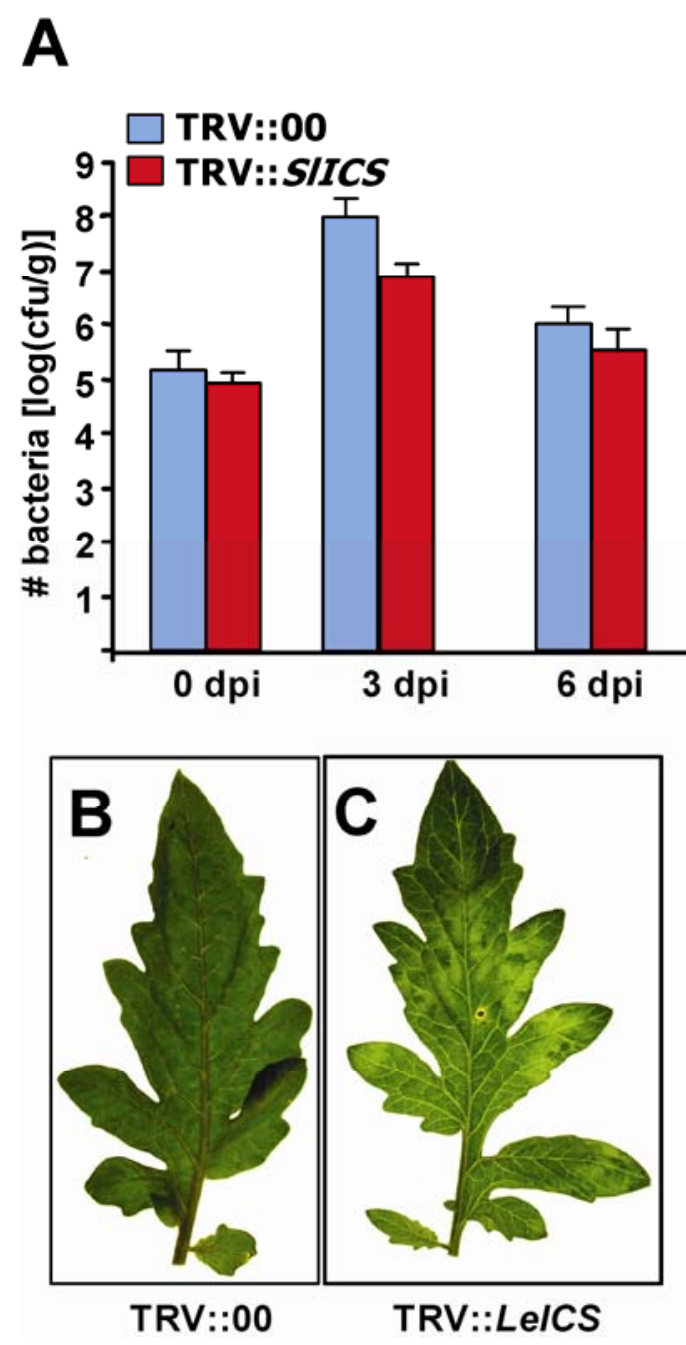

Fig. 7. Bacterial growth and symptom production in DB29-inoculated TRV::00 and SlICS-silenced tomatoes (cv. Glamour). A, Growth of DB29 in TRV::00 and TRV::SlICS plants. Error bars represent the standard deviation of four independent samples. Symptoms produced by DB29 on B, TRV::00 or C, TRV::SlICS tomato lines at 6 days post inoculation (dpi). 
Fig. S2), NahG tomato plants exhibited aberrant symptoms when inoculated with DC3000. In contrast, DB29 failed to induce lesions on Moneymaker or NahG plants. DC3000 and DB29 colonized NahG tomato at similar, high levels during the first 3 dpi; however, the population of DB29 was slightly lower than DC3000 at 6 dpi. Thus, results obtained with $N a h G$ tomato plants did not lead to meaningful conclusions regarding the role of COR in disease development and SA-mediated defense.

It has been reported that the catechol generated in $N a h G$ lines of $A$. thaliana can interfere with nonhost resistance (van Wees and Glazebrook 2003). Furthermore, NahG tomato plants are known to form spontaneous necrotic lesions in a temperature-dependent manner ( $\mathrm{Li}$ et al. 2002), thus confounding conclusions regarding the role of SA. Mutant plant lines defective in SA biosynthesis, such as the ICSI lines of A. thaliana, offer an attractive alternative for assessing the role of SA in plantmicrobe interactions (Brooks et al. 2005; Heck et al. 2003; Huang et al. 2005; Wildermuth et al. 2001). In the present study, we cloned and transiently silenced ICS in tomato; although two orthologs of ICS were reported in A. thaliana (Wildermuth et al. 2001), a second copy of ICS was not recovered from tomato by RACE. However, regardless of whether a second copy exists, the SIICS-silenced tomato lines accumulated lower levels of SA (Fig. 5A), exhibited reduced expression of SA-mediated PR proteins (Fig. 6), and were more susceptible to DC3000 infection (Fig. 5H) compared with TRV::00-infected plants. These results indicate that SA or SA-mediated defense responses function to limit either the growth or virulence of DC3000.

One of the hallmarks of $P$. syringae pv. tomato disease development on tomato leaves is the formation of necrotic lesions surrounded by chlorosis. The most prominent symptom observed in leaves treated with COR or infected with COR-producing strains of $P$. syringae is an intense spreading chlorosis (Gnanamanickam et al. 1982; Palmer and Bender 1995; Uppalapati et al. 2005; Zhao et al. 2003). In a previous study, Mach and associates (2001) demonstrated that purified COR triggered accelerated cell death in $a c d 2$ mutants of $A$. thaliana. Acd 2 encodes a red chlorophyll catabolite reductase, which suppresses the spread of disease symptoms in A. thaliana (Mach et al. 2001). Based on these results and our observations that DB29 failed to cause symptoms on SIICS lines, it is tempting to speculate that, along with defense suppression (Block et al. 2005; Brooks et al. 2005; Kloek et al. 2001; LaurieBerry et al. 2006; Melotto et al. 2006; Zhao et al. 2003), CORinduced chlorosis may promote cell death in tomato.

It also is plausible that the absence of COR compromises other aspects of the virulence machinery in DC3000. For example, COR or COR-dependent signals may help DC3000 enter the necrogenic phase and promote the formation of typical disease lesions in tomato. Several studies have demonstrated cross-talk between COR and the type III secretion system (TTSS) in DC3000 (Boch et al. 2002; Fouts et al. 2002; He et al. 2004; Peñaloza-Vázquez et al. 2000; Sreedharan et al. 2006; Thilmony et al. 2006; Zhao et al. 2003). Thus, the onset of the necrogenic phase may involve a coordinated regulation of COR and proteins secreted by the TTSS in DC3000. Studies designed to investigate gene expression in both the host and pathogen will further elucidate the function of COR in pathogen fitness and pathogenesis.

\section{MATERIALS AND METHODS}

\section{Plant material.}

Seed of tomato cv. Glamour were obtained from Stokes Seeds, Inc. (Buffalo, NY, U.S.A.); seed of cv. Moneymaker and the NahG transgenic line (Brading et al. 2000) were kindly provided by J. Jones (Sainsbury Laboratory, John Innes Centre, Norwich, U.K.). Plants were grown from seed in Scott-200 mix (The Scotts Co., Marysville, OH, U.S.A.) in 10-cm-diameter plastic pots and maintained in growth chambers $\left(24^{\circ} \mathrm{C}, 40\right.$ to $70 \% \mathrm{RH}, 12-\mathrm{h}$ photoperiod, photon flux density 150 to 200 $\mu \mathrm{mol} \mathrm{m} \mathrm{m}^{-2} \mathrm{~s}^{-1}$ ). Inoculation assays were conducted on 4-weekold plants.

\section{Bacterial strains and pathogen infection assays.}

P. syringae pv. tomato DC3000 and mutants AK7E2 $\left(\mathrm{CFA}^{+}\right.$ $\mathrm{CMA}^{-}$; cmaA::Tn5), DB4G3 (CFA $\left.{ }^{-} \mathrm{CMA}^{+} ; c f a 6:: \operatorname{Tn} 5\right)$, and DB29 ( $\mathrm{CFA}^{-} \mathrm{CMA}^{-}$; $c f a 6$-cmaA double mutant) (Brooks et al. 2004) were grown at $28^{\circ} \mathrm{C}$ on King's B medium (KB) (King et al. 1954). Antibiotics were added to media in the following concentrations: rifampicin at $100 \mu \mathrm{g} / \mathrm{ml}$, kanamycin at 25 $\mu \mathrm{g} / \mathrm{ml}$, and spectinomycin at $25 \mu \mathrm{g} / \mathrm{ml}$.

In pathogen infection assays, 4-week-old tomato plants were spray inoculated to runoff with a bacterial suspension (optical density at $600 \mathrm{~nm}\left[\mathrm{OD}_{600}\right]=0.2$ ) in distilled water containing $0.0025 \%$ Silwet L-77 (OSi Specialties Inc., Danbury, CT, U.S.A.). The inoculated plants then were incubated in growth chambers at 90 to $100 \% \mathrm{RH}$ for the first $24 \mathrm{~h}$ and at approximately $70 \% \mathrm{RH}$ for the rest of the experimental period. High humidity was achieved by placing a cool mist humidifier (ReliOn, 2 gallons/day) in the growth chamber. Although bacterial cell concentrations were determined routinely based on turbidity, the actual number of bacterial cells on spray-inoculated leaves initially was determined by harvesting leaves and plating to selective media. The CFU measurement determined in this manner was used to quantify the initial inoculum concentration at 0 dpi (Fig. 1A). Pathogen colonization was monitored by estimating the internal bacterial population of inoculated leaves at $0,1,3$, and $6 \mathrm{dpi}$. To estimate internal populations, leaves were surface sterilized with $15 \% \mathrm{H}_{2} \mathrm{O}_{2}$ for 5 min to eliminate epiphytic bacteria, washed three times with sterile distilled water, and then homogenized in distilled water. Quantification of total bacteria in DC3000-inoculated TRV::00 and TRV::SIICS lines was performed by collecting leaf discs at various times after inoculation. Leaf discs were sampled from areas where maximum silencing was observed based on the slight variegated phenotype (data not shown). Leaf discs then were homogenized in sterile distilled water, and a dilution series (100- $\mu 1$ aliquots) was plated on KB medium supplemented with the appropriate antibiotics. All treatments were examined in at least three separate experiments. Disease symptoms were evaluated visually 3,4 , and 6 days after inoculation.

\section{pTRV:: SlICS-vector construction and VIGS.}

The vectors $p T R V 1$ and $p T R V 2$ VIGS (Liu et al. 2002) were kindly provided by S. P. Dinesh-Kumar, Yale University, New Haven, CT, U.S.A. A 440-bp fragment of SIICS (GenBank accession number DQ149918) was amplified from tomato (cv. Glamour) by RT-PCR using primers pSlICSattB1: 5'-GGG GAC AAG TTT GTA CAA AAA AGC AGG CTT CGC CGG CAT TCA TTG GAA ACA-3' and $p$ SlICSattB2: 5'-GGG GAC CAC TTT GTA CAA GAA AGC TGG GTA AAG CCC GTG CAT CTT CTG T-3'. The PCR-amplified gene fragments were introduced into GATEWAY-ready $p T R V 2$ (Liu et al. 2002). TRV::LePDS (PDS encodes phytoene desaturase) was used as a positive control for VIGS and has been described previously (Ryu et al. 2004). The inserts and PCR fragments were verified by sequencing. Plasmids were introduced into Agrobacterium tumefaciens GV2260 (An 1987) by electroporation.

A combination of improved Agrodrench (Ryu et al. 2004) and seedling infiltration (Ekengren et al. 2003) methods were used to introduce transformed A. tumefaciens derivatives (strain 
GV2260 harboring different pTRV2-VIGS constructs and pTRV1) into tomato plants. A. tumefaciens cultures containing pTRV1 and $p T R V 2$-VIGS were grown overnight on LuriaBertani medium (Sambrook et al. 1989) at $28^{\circ} \mathrm{C}$ with antibiotic selection (rifampicin and kanamycin at $50 \mu \mathrm{g} / \mathrm{ml}$ each). Bacterial cells were harvested and resuspended in induction medium (10 mM $\mathrm{MgCl}_{2}, 10 \mathrm{mM}$ MES, pH 5.6) supplemented with $150 \mu \mathrm{M}$ acetosyringone and incubated at room temperature on an orbital shaker for 5 to $6 \mathrm{~h}$. The acetosyringoneinduced bacterial cultures containing $p T R V 1$ and $p T R V 2-$ VIGS then were mixed in equal ratios $\left(\mathrm{OD}_{600}=1.0\right)$, and a combination of Agroinfiltration (Ekengren et al. 2003) and Agrodrench (Ryu et al. 2004) was used for VIGS. Approximately 30 to 35 plants were used for each experiment and were inoculated with empty vector (TRV::00; 5 plants), TRV::SIICS (20 to 25 plants), or TRV::LePDS (5 plants). A photobleaching phenotype was observed on the leaves of the $P D S$-silenced plants at 2 to 3 weeks postinfection (Supplementary Fig. S3), indicating that gene silencing by VIGS was effective. The experiment was repeated at least three times.

\section{Cloning of full-length SIICS and semiquantitative RT-PCR.}

To facilitate the cloning of ICS from $S$. lycopersicum, two primers, 5'-TCG CCG GCA TTC ATT GGA AAC A-3' and 5'AAA GCC CGT GCA TCT TCT GT-3', were designed based on conserved regions of ICS genes from Nicotiana tabacum (GenBank AY740529 and AB182580), Capsicum annum (GenBank AY743431), and Solanum pennellii (GenBank AW398687). To enrich for ICS transcripts, total RNA was isolated from $S$. lycopersicum cv. Glamour leaves $24 \mathrm{~h}$ after inoculation with DB29. RNA was isolated using TRIzol (Invitrogen, Carlsbad, CA, U.S.A.) and treated with RNase-free DNase I as recommended (Promega Corp., Madison, WI, U.SA). Specific 5' and 3' RACE primers then were designed based on a 440-bp tomato expressed sequence tag (GenBank accession number DQ149918), and the FirstChoice RNAligase-mediated RACE kit (Ambion, Inc., Austin, TX, U.S.A.) was used to clone full-length ICS from $S$. lycopersicum. Two primers were designed for 5'-RACE: 5'-GAT CCA GAA GCT CTG ATC CA-3' and 5'-CTA AAG CCT CAC TAC AAA TGC T-3'; the primers for $3^{\prime}$-RACE were 5'-GTA TCC TAC AGA AGA TGC ACG G-3' and 5'-GAT ATT GTC ATC CGT GCA CCC T-3'. The RACE products were cloned into pGMET (Promega Corp.) and sequenced. Based on the RACE fragment sequences, a pair of primers (5'-ATC TTA ATG GCT GTA GGT GTA AGG CAC T-3' and 5'-GAG GTG CCT CAA GTT TCA TCA ATT TG-3') then was designed, spanning the untranslated regions to PCR amplify a full-length cDNA, which was cloned into pGMET and sequenced. The full-length cDNA sequence for SlICS was submitted to GenBank (DQ984132). Multiple sequence alignments of ICS proteins were performed using ClustalW and online resources available at Biology Workbench. MView was used for calculation of percentage identities among ICS sequences (Brown et al. 1998).

Semiquantitative RT-PCR was conducted with cDNA generated as described for real-time qPCR. For semiquantitative RTPCR, $1 \mu \mathrm{l}$ of first-strand cDNA (diluted 1:50 in reaction buffer) was amplified using Taq DNA polymerase (Promega Corp.). To confirm the amplification of endogenous genes, gene-specific primers that anneal outside the 440-bp region targeted for SIICS silencing were used. PCR amplifications were performed for 25 and 30 cycles, and $10 \mu \mathrm{l}$ of the PCR product was separated on a $1.5 \%$ agarose gel. To check for equal amounts of cDNA in each reaction, PCR was performed with primers specific for the gene encoding $\alpha$-tubulin 4 (Uppalapati et al. 2005) or EF-1 $\alpha$ (5'-ACG CTT GAG ATC CTT AAC CGC AAC ATT CTT-3' and 5'-TGG TGT CCT
CAA GCC TGG TAT GGT TGT-3'). The intensities of PCR products were quantified using Scion Image (version beta 4.0.3; Scion Corporation, Fredrick, MD, U.S.A.).

\section{RNA extraction, PCR, and Northern blot analysis.}

Total RNA was purified from tomato seedlings inoculated with DC3000 and DB29 at $24 \mathrm{~h}$ postinoculation using TRIzol according to the manufacturer's instructions (Invitrogen). Expression of selected JA-responsive and SA-dependent genes was analyzed using real-time qPCR. Primers were designed using the full-length $S$. lycopersicum cDNAs available from GenBank (DQ984132). The primers used to amplify $P R-1 b$ were 5'-CAC AAA AGT ATG CCA ACT CAA GAG C-3' and $5^{\prime}$-TCT CCC CAG CAC CAG AAT GAA TC-3'. $P R-2 b$ was amplified using 5'-CGA GAT GGT GGG TAC AGA AGA AC$3^{\prime}$ and 5'-CAA GAT TGG AAG TGC CAG TAA CAG G-3', and SIICS was amplified using 5'-TCG CCG GCA TTC ATT CAT TGG AAA CA-3' and 5'-AAA GCC CGT GCA TCT TCT GT-3'. $\alpha$-Tubulin $4, L O X D$, and $P I-I I$ were amplified using primers described previously (Mysore et al. 2002; Uppalapati et al. 2005). Primers were designed using Beacon Designer 2.13 software (Premier Biosoft International, Palo Alto, CA, U.S.A.). Melt-curve analysis was performed to monitor primer-dimer formation and to check for amplification of gene-specific products.

cDNA synthesis and real-time qPCR were performed using methods described previously (Uppalapati et al. 2005). Briefly, $6 \mu \mathrm{g}$ of total RNA was incubated with DNase I, and cDNA was synthesized using Superscript II reverse transcriptase. cDNA (equivalent to $10 \mathrm{ng}$ of initial RNA) was quantified using gene-specific primers, SYBR Green reagents, and the iCycler iQ Real-Time PCR Detection System (Bio-Rad, Hercules, CA, U.S.A.). Data quantification and analysis was performed using iCycler software (ver. 3.06.6070) and Gene Expression Macro (ver. 1.1) (Bio-Rad) with the algorithms described by Vandesompele and associates (2002).

The average threshold cycle values were calculated from triplicate samples and used to determine the fold expression relative to the controls. Primers specific for $\alpha$-tubulin 4 were used to normalize small differences in template amounts.

Semiquantitative RT-PCR was conducted with cDNA generated as described for qPCR. Following RNase-free DNase (RQ1; Promega Corp.) treatment, cDNA was synthesized from $5 \mu \mathrm{g}$ of total RNA using SuperScript RNase $\mathrm{H}^{-} \mathrm{RT}$ and oligo dT primers using protocols recommended by the manufacturer (Invitrogen). For semiquantitative PCR, $1 \mu \mathrm{l}$ of first-strand cDNA (diluted 1:50 in reaction buffer) was amplified using Taq DNA polymerase (Promega Corp.). To confirm the amplification of endogenous genes, gene-specific primers that anneal outside the 440-bp region targeted for SIICS silencing were used. PCR amplifications were performed for 25 and 30 cycles, and $10 \mu \mathrm{l}$ of the PCR product was separated on a $1.5 \%$ agarose gel. To check for equal amounts of cDNA in each reaction, PCR was performed with primers specific for the gene encoding $\alpha$-tubulin 4 (Uppalapati et al. 2005) or elongation factor $1 \alpha\left(E F-1 \alpha 5^{\prime}\right.$-ACG CTT GAG ATC CTT AAC CGC AAC ATT CTT-3' and 5'-TGG TGT CCT CAA GCC TGG TAT GGT TGT-3'). The intensities of PCR products were quantified using Scion Image (version Beta 4.0.3; Scion Corporation).

Northern blot analysis was carried out as described by Sugimoto and associates (2000). PR- $1 b$ PCR products were generated using gene-specific primers and used for probe preparation. Digoxigenin (DIG)-labeled $P R-1 b$ was detected using anti-DIG and visualized with the chemiluminescence substrate, CDP-Star (Roche Applied Science, Mannheim, Germany). 


\section{SA quantification.}

Tomato leaves (approximately $450 \mathrm{mg}$ ) were extracted and analyzed for SA as described by Schmelz and associates (2003) using a quadropole gas chromatography-mass spectrometry system (Agilent, Palo Alto, CA, U.S.A.) connected to a mass selective detector (Agilent) with selective-ion monitoring (SIM, selected ion \pm 0.5 mass unit) in positive chemical ionization or electron ionization (EI) mode. SA was separated on a RTx -5 column ( $30 \mathrm{~m}$ by $0.25 \mathrm{~mm}$ by $0.25 \mathrm{~mm}$ ) (Restek, Bellefonte, PA, U.S.A.) using conditions described previously (Schmelz et al. 2003; Uppalapati et al. 2005). SA quantification in SIICS-silenced plants was done in EI mode with SIM. The retention times and mass units of the methyl esters analyzed were: SA-ME $(8.35 \mathrm{~min}, 153 / 152)$ and $\left[{ }^{2} \mathrm{H}_{6}\right] \mathrm{SA}-\mathrm{ME}$ (8.33 min, 157/156). Isotopically labeled SA was purchased from CDN Isotopes (Pointe-Claire, Quebec, Canada).

\section{ACKNOWLEDGMENTS}

We thank L. Sumner, D. Jones, E. Schmelz, and J. Dillwith for helpful discussions on gas chromatography-mass spectrometry analysis and $\mathrm{K} . \mathrm{Li}$ for technical assistance. B. N. Kunkel and C. L. Bender acknowledge support from the National Science Foundation (IBN-0130693 and IOB0620469) and the Oklahoma Agricultural Experiment Station (C. L. Bender). K. S. Mysore acknowledges support from the Noble Foundation.

\section{LITERATURE CITED}

Abramovitch, R. B., and Martin, G. B. 2004. Strategies used by bacterial pathogens to suppress plant defenses. Curr. Opin. Plant Biol. 7:356-364.

An, G. 1987. Binary Ti vectors for plant transformation and promoter analysis. Methods Enzymol. 153:292-305.

Bender, C. L., Stone, H. E., Sims, J. J., and Cooksey, D. A. 1987. Reduced pathogen fitness of Pseudomonas syringae pv. tomato Tn5 insertions defective in coronatine production. Physiol. Mol. Plant Pathol. 30:273283.

Bender, C. L., Alarcón-Chaidez, F., and Gross, D. C. 1999. Pseudomonas syringae phytotoxins: Mode of action, regulation and biosynthesis by peptide and polyketide synthetases. Microbiol. Mol. Biol. Rev. 63:266-292.

Block, A., Schmelz, E., Jones, J. J., and Klee. H. J. 2005. Coronatine and salicylic acid: The battle between Arabidopsis and Pseudomonas for phytohormone control. Mol. Plant Pathol. 6:79-83.

Boch, J., Joardar, V., Gao, L., Robertson, T. L., Lim, M., and Kunkel, B. N. 2002. Identification of Pseudomonas syringae pv. tomato genes induced during infection of Arabidopsis thaliana. Mol. Microbiol. 44:73-88.

Brading, P. A., Hammond-Kosack, K. E., Parr, A., and Jones, J. D. 2000. Salicylic acid is not required for Cf-2- and Cf-9-dependent resistance of tomato to Cladosporium fulvum. Plant J. 23:305-318.

Brooks, D. M., Guzman, G. H., Kloek, A. P., Alarcón-Chaidez, F., Sreedharan, A., Rangaswamy, V., Peñaloza-Vázquez, A., Bender, C. L., and Kunkel, B. N. 2004. Identification and characterization of a welldefined series of coronatine biosynthetic mutants of Pseudomonas syringae pathovar tomato DC3000. Mol. Plant-Microbe Interact. 17:162174

Brooks, D. M., Bender, C. L., and Kunkel, B. N. 2005. The Pseudomonas syringae phytotoxin coronatine promotes virulence by overcoming salicylic acid-dependent defences in Arabidopsis thaliana. Mol. Plant Pathol. 6:629-639.

Brown, N. P., Leroy, C., and Sander, C. 1998. MView: A web compatible database search or multiple alignment viewer. Bioinformatics 14:380-381.

Buell, C. R., Joardar, V., Lindeberg, M., Selengut, J., Paulsen, I. T., Gwinn, M. L., Dodson, R. J., Deboy, R. T., Durkin, A. S., Kolonay, J. F. F., Madupu, R., Daugherty, S., Brinkac, L., Beanan, M. J., Haft, D. H., Nelson, W. C., Davidsen, T., Liu, J., Yuan, Q., Khouri, H., Fedorova, N., Tran, B., Russell, D., Berry, K., Utterback, T., Vanaken, S. E., Feldblyum, T. V., D’Ascenzo, M., Deng, W.-L., Ramos, A. R., Alfano, J. R., Cartinhour, S., Chatterjee, A. K., Delaney, T. P., Lazarowitz, S. G., Martin, G. B., Schneider, D. J., Tang, X., Bender, C. L., White, O., Fraser, C. M., and Collmer, A. 2003. The complete genome sequence of the Arabidopsis and tomato pathogen Pseudomonas syringae pv. tomato DC3000. Proc. Natl. Acad. Sci. U.S.A. 100:10181-10186.

Cao, H., Bowling, S. A., Gordon, A. S., and Dong, X. 1994. Characterization of an Arabidopsis mutant that is nonresponsive to inducers of systemic acquired resistance. Plant Cell 6:1583-1592.

Delaney, T. P., Uknes, S., Vernooij, B., Friedrich, L., Weyman, K.,
Negrotto, D., Gaffney, T., Gut-Reila, M., Kessman, H., Ward, E., and Ryals, J. 1994. A central role of salicylic acid in plant disease resistance. Science 266:1247-1250.

Dong, X. 1998. SA, JA, ethylene, and disease resistance in plants. Curr. Opin. Plant Biol. 1:316-323.

Durner, J., Shah, J., and Klessig, D. F. 1997. Salicylic acid and disease resistance in plants. Crit. Rev. Plant. Sci. 18:547-575.

Ekengren, S. K., Liu, Y., Schiff, M., Dinesh-Kumar, S. P., and Martin, G. B. 2003. Two MAPK cascades, NPR1, and TGA transcription factors play a role in Pto-mediated disease resistance in tomato. Plant J. 36:905-917.

Elizabeth, S. V., and Bender, C. L. 2007. The phytotoxin coronatine from Pseudomonas syringae pv. tomato DC3000 functions as a virulence factor and influences defense pathways in edible Brassicas. Mol. Plant Pathol. 8:83-92.

Espinosa, A., Guo, M., Tam, V. C., Fu, Z. Q., and Alfano, J. R. 2003. The Pseudomonas syringae type III-secreted protein HopPtoD2 possesses protein tyrosine phosphatase activity and suppresses programmed cell death in plants. Mol. Microbiol. 49:377-387.

Eulgem, T. 2005. Regulation of the Arabidopsis defense transcriptome. Trends Plant Sci. 10:71-78.

Feys, B. J. F., Benedetti, C. E., Penfold, C. N., and Turner, J. G. 1994. Arabidopsis mutants selected for resistance to the phytotoxin coronatine are male sterile, insensitive to methyl jasmonate, and resistant to a bacterial pathogen. Plant Cell 6:751-759.

Fouts, D. E., Abramovitch, R. B., Alfano, J. R., Baldo, A. M., Buell, C. R., Cartinhour, S., Chatterjee, A. K., D'Ascenzo, M., Gwinn, M. L. Lazarowitz, S. G., Lin, N. C., Martin, G. B., Rehm, A. H., Schneider, D. J., van Dijk, K., Tang, X., and Collmer, A. 2002. Genomewide identification of Pseudomonas syringae pv. tomato DC3000 promoters controlled by the HrpL alternative sigma factor. Proc. Natl. Acad. Sci. U.S.A. 99:2275-2280.

Glazebrook, J. 2005. Contrasting mechanisms of defense against biotrophic and necrotrophic pathogens. Annu. Rev. Phytopathol. 43:205-227.

Glazebrook, J., Rogers, E. E., and Ausubel, F. M. 1996. Isolation of Arabidopsis mutants with enhanced disease susceptibility by direct screening. Genetics 143:973-982.

Glazebrook, J., Chen, W., Estes, B., Chang, H. S., Nawrath, C., Metraux, J. P., Zhu, T., and Katagiri, F. 2003. Topology of the network integrating salicylate and jasmonate signal transduction derived from global expression phenotyping. Plant J. 34:217-228.

Gnanamanickam, S. S., Starratt, A. N., and Ward, E. W. B. 1982. Coronatine production in vitro and in vivo and its relation to symptom development in bacterial blight of soybean. Can. J. Bot. 60:645-650.

He, P., Chintamanani, S., Chen, Z., Zhu, L., Kunkel, B. N., Alfano, J. R., Tang, X., and Zhou, J. M. 2004. Activation of a COI1-dependent pathway in Arabidopsis by Pseudomonas syringae type III effectors and coronatine. Plant J. 37:589-602.

Heck, S., Grau, T., Buchala, A., Metraux, J. P., and Nawrath, C. 2003. Genetic evidence that expression of NahG modifies defence pathways independent of salicylic acid biosynthesis in the Arabidopsis-Pseudomonas syringae pv. tomato interaction. Plant J. 36:342-352.

Heitz, T., Bergey, D. R., and Ryan, C. A. 1997. A gene encoding a chloroplast-targeted lipoxygenase in tomato leaves is transiently induced by wounding, systemin, and methyl jasmonate. Plant Physiol. 114:10851093

Huang, Z., Yeakley, J. M., Garcia, E. W., Holdridge, J. D., Fan, J. B., and Whitham, S. A. 2005. Salicylic acid-dependent expression of host genes in compatible Arabidopsis-virus interactions. Plant Physiol. 137:11471159

Imanishi, S., Nakakita, M., Yamashita, K., Furata, A., Utsuno, K. Muramoto, N., Kojima, H., and Nakamura, K. 2000. Aspirin and salicylic acid do not inhibit methyl jasmonate-inducible expression of a gene for ornithine decarboxylase in tobacco BY-2 cells. Biosci. Biotechnol. Biochem. 64:125-133.

Jakobek, J. L., Smith, J. A., and Lindgren, P. B. 1993. Suppression of bean defense responses by Pseudomonas syringae. Plant Cell 5:57-63.

Katagiri, F. 2004. A global view of defense gene expression regulation-A highly interconnected signaling network. Curr. Opin. Plant Biol. 7:506511.

King, E. O., Ward, N. K., and Raney, D. E. 1954. Two simple media for the demonstration of pyocyanin and fluorescein. J. Lab Clin. Med. 44:301-307.

Kloek, A. P., Verbsky, M. L., Sharma, S. B., Schoelz, J. E., Vogel, J., Klessig, D. F., and Kunkel, B.N. 2001. Resistance to Pseudomonas syringae conferred by an Arabidopsis thaliana coronatine-insensitive coil mutation occurs through two distinct mechanisms. Plant J. 26:509-522.

Kunkel, B. N., and Brooks, D. M. 2002. Cross talk between signaling pathways in pathogen defense. Curr. Opin. Plant Biol. 5:325-331.

Kunkel, B. N., and Chen, Z. 2005. Virulence strategies of plant pathogenic bacteria. In: The Prokaryotes: An Evolving Electronic Resource for the 
Microbiological Community, Release 3.20. M. Dworkin, ed. SpringerVerlag, New York.

Laurie-Berry, N., Joardar, V., Street, I. H., and Kunkel, B. N. 2006. The Arabidopsis thaliana Jasmonate Insensitive 1 gene defines a branch of the jasmonate signaling pathway required for suppression of salicylic acid-dependent defenses during infection by $P$. syringae. Mol. PlantMicrobe Interact. 19:789-800.

Leon, J., Rojo, E., and Sanchez-Serrano, J. J. 2001. Wound signaling in plants. J. Exp. Bot. 52:1-9.

Li, J., Shan, L., Zhou, J.-M., and Tang, X. 2002. Overexpression of Pto induces a salicylate-independent cell death but inhibits necrotic lesions caused by salicylate-deficiency in tomato plants. Mol. Plant-Microbe Interact. 15:654-661.

Lim, M. T., and Kunkel, B. N. 2005. The Pseudomonas syringae avrRpt2 gene contributes to virulence on tomato. Mol. Plant-Microbe Interact. 18:626-633.

Liu, Y., Schiff, M., and Dinesh-Kumar, S. P. 2002. Virus-induced gene silencing in tomato. Plant J. 31:777-786.

Lund, S. T., Stall, R. E., and Klee, H. J. 1998. Ethylene regulates the susceptible response to pathogen infection in tomato. Plant Cell 10:371-382.

Ma, S.-W., Morris, V. L., and Cuppels, D. A. 1991. Characterization of a DNA region required for production of the phytotoxin coronatine by Pseudomonas syringae pv. tomato. Mol. Plant-Microbe Interact. 4:69-74.

Mach, J. M., Castillo, A. R., Hoogstraten, R., and Greenberg, J. T. 2001. The Arabidopsis-accelerated cell death gene ACD2 encodes red chlorophyll catabolite reductase and suppresses the spread of disease symptoms. Proc. Natl. Acad. Sci. U.S.A. 98:771-776.

Melotto, M., Underwood, W., Koczan, J., Nomura, K., and He, S. Y. 2006. Plant stomata function in innate immunity against bacterial invasion. Cell 126:969-980.

Mitchell, R. E. 1984. A naturally-occurring structural analogue of the phytotoxin coronatine. Phytochemistry 23:791-793.

Mitchell, R. E., and Ford, K. L. 1998. Chlorosis-inducing products from Pseudomonas syringae pathovars: New $N$-coronafacoyl compounds. Phytochemistry 49:1579-1583.

Mittal, S. M., and Davis, K. R. 1995. Role of the phytotoxin coronatine in the infection of Arabidopsis thaliana by Pseudomonas syringae pv. tomato. Mol. Plant-Microbe Interact. 8:165-171.

Mudgett, M. B. 2005. New insights to the function of phytopathogenic bacterial type III effectors in plants. Annu. Rev. Plant Biol. 56:509-531.

Mur, L. A. J., Kenton, P., Atzorn, R., Miersch, O., and Wasternack, C. 2006. The outcomes of concentration-specific interactions between salicylate and jasmonate signaling include synergy, antagonism, and oxidative stress leading to cell death. Plant Physiol. 140:249-262.

Mysore, K. S., Crasta, O. R., Tuori, R. P., Folkerts, O., Swirsky, P. B., and Martin, G. B. 2002. Comprehensive transcript profiling of Pto- and Prfmediated host defense responses to infection by Pseudomonas syringae pv. tomato. Plant J. 32:299-315.

Nawrath, C., and Metraux, J. P. 1999. Salicylic acid induction-deficient mutants of Arabidopsis express $P R-2$ and PR-5 and accumulate high levels of camalexin after pathogen inoculation. Plant Cell 11:1393-1404.

O’Donnell, P. J., Schmelz, E., Block, A., Miersch, O., Wasternack, C., Jones, J. B., and Klee, H. J. 2003. Multiple hormones act sequentially to mediate a susceptible tomato pathogen defense response. Plant Physiol. 133:11811189.

Oldroyd, G. E. D., and Staskawicz, B. J. 1998. Genetically engineered broad-spectrum disease resistance in tomato. Proc. Natl. Acad. Sci. U.S.A. 95:10300-10305.

Palmer, D. A., and Bender, C. L. 1995. Ultrastructure of tomato leaf tissue treated with the pseudomonad phytotoxin coronatine and comparison with methyl jasmonate. Mol. Plant-Microbe Interact. 8:683-692.

Pena-Cortes, H., Fisahn, J., and Willmitzer, L. 1995. Signals involved in wound-induced proteinase inhibitor II gene expression in tomato and potato plants. Proc. Natl. Acad. Sci. U.S.A. 92:4106-4113.

Peñaloza-Vázquez, A., Preston, G. M., Collmer, A., and Bender, C. L. 2000. Regulatory interactions between the Hrp type III protein secretion system and coronatine biosynthesis in Pseudomonas syringae pv. tomato DC3000. Microbiology 146:2447-2456.

Ryals, J. A., Neuenschwander, U. H., Willits, M. G., Molina, A., Steiner, H. Y., and Hunt, M. D. 1996. Systemic acquired resistance. Plant Cell 8:1809-1819.

Ryu, C. M., Anand, A., Kang, L., and Mysore, K. S. 2004. Agrodrench: A novel and effective agroinoculation method for virus-induced gene silencing in roots and diverse solanaceous species. Plant J. 40:322-331.
Sambrook, J., Fritsch, E. F., and Maniatis, T. 1989. Molecular Cloning: A Laboratory Manual, 2nd ed. Cold Spring Harbor Laboratory Press, Cold Spring Harbor, NY, U.S.A.

Schmelz, E. A., Engelberth, J., Alborn, H. T., O’Donnell, P., Sammons, M., Toshima, H., and Tumlinson, J. H. 2003. Simultaneous analysis of phytohormones, phytotoxins, and volatile organic compounds in plants. Proc. Natl. Acad. Sci. U.S.A. 100:10552-10557.

Shah, J. 2003. The salicylic acid loop in plant defense. Curr. Opin. Plant Biol. 6:365-371.

Spoel, S.H., Koornneef, A., Claessens, S.M., Korzelius, J. P., Van Pelt, J. A., Mueller, M. J., Buchala, A. J., Metraux, J. P., Brown, R., Kazan, K. Van Loon, L. C., Dong, X., and Pieterse, C. M. 2003. NPR1 modulates cross-talk between salicylate- and jasmonate-dependent defense pathways through a novel function in the cytosol. Plant Cell 15:760-770.

Sreedharan, A., Peñaloza-Vazquez, A., Kunkel, B. N., and Bender. C. L. 2006. CorR regulates multiple components of virulence in Pseudomonas syringae pv. tomato DC3000. Mol. Plant-Microbe Interact. 19:768-779.

Staswick, P. E., and Tiryaki, I. 2004. The oxylipin signal jasmonic acid is activated by an enzyme that conjugates it to isoleucine in Arabidopsis. Plant Cell 16:2117-2127.

Sugimoto, M., Toyoda, K., Ichinosae, Y., Yamada, T., and Shiraishi, T. 2000. Cytochalasin A inhibits the binding of phenylalanine ammonialyase mRNA to ribosomes during induction of phytoalexin in pea seedlings. Plant Cell Physiol. 41:234-238.

Thaler, J. S., Fidantsef, A. L, and Bostock, R. M. 2002. Antagonism between jasmonate- and salicylate-mediated induced plant resistance: Effects of concentration and timing of elicitation on defense-related proteins, herbivore, and pathogen performance in tomato. J. Chem. Ecol. 28:1131-1159.

Thilmony, R., Underwood, W., and He, S. Y. 2006. Genome-wide transcriptional analysis of the Arabidopsis thaliana interaction with the plant pathogen Pseudomonas syringae pv. tomato DC3000 and the human pathogen Escherichia coli O157:H7. Plant J. 46:34-53.

Thomma, B. P., Penninckx, I. A., Broekaert, W. F., and Cammue, B. P. 2001. The complexity of disease signaling in Arabidopsis. Curr. Opin. Immunol. 13:63-68.

Truman, W., Bennett, M. H., Kubigsteltig, I., Turnbull, C., and Grant, M. 2007. Arabidopsis systemic immunity uses conserved defense signaling pathways and is mediated by jasmonates. Proc. Natl. Acad. Sci. U.S.A. 104:1075-1080.

Uppalapati S. R., Yasuhiro, I., Toyoda, K., Ichinose, Y., and Shiraishi, T. 2004. Differential regulation of MBP kinases by a glycoproptein elicitor and a polypeptide suppressor from Mycosphaerella pinodes in pea. Physiol. Mol. Plant Pathol. 64:17-25.

Uppalapati, S. R., Patricia A., Weng, H., P., Palmer, D. A., Mitchell, R.E., Jones, W., and Bender, C. L. 2005. The phytotoxin coronatine and methyl jasmonate impact multiple phytohormone pathways in tomato. Plant J. 42:201-217.

Vandesompele, J., De Preter, K., Pattyn, F., Poppe, B., Van Roy, N., De Paepe, A., and Speleman, F. 2002. Accurate normalization of real-time quantitative RT-PCR data by geometric averaging of multiple internal control genes. Genome Biol. 3:0034.1-0034.11

van Wees, S. C., and Glazebrook, J. 2003. Loss of non-host resistance of Arabidopsis NahG to Pseudomonas syringae pv. phaseolicola is due to degradation products of salicylic acid. Plant J. 33:733-742.

Vidya, C. S. S., Manoharan, M., and Sita, G. L. 1999. Cloning and characterization of salicylic acid-induced, intracellular pathogenesis related gene from tomato Lycopersicon esculentum. J. Biosci. 24:287-293.

Weiler, E. W., Kutchan, T. M., Gorba, T., Brodschelm, W., Neisel, U., and Bublitz, F. 1994. The Pseudomonas phytotoxin coronatine mimics octadecanoid signaling molecules of higher plants. FEBS (Fed. Eur. Biol. Soc.) Lett. 345:9-13.

Wildermuth, M. C., Dewdney, J., Wu, G., and Ausubel, F. M. 2001. Isochorismate synthase is required to synthesize salicylic acid for plant defence. Nature 414:562-565.

Zhao, Y., Thilmony, R., Bender, C. L., Schaller, A., He, S. Y., and Howe, G. A. 2003. Virulence systems of Pseudomonas syringae pv. tomato promote bacterial speck disease in tomato by targeting the jasmonate signaling pathway. Plant J.36:485-499.

\section{AUTHOR-RECOMMENDED INTERNET RESOURCE}

Biology Workbench, http://www.workbench.sdsc.edu 